\title{
Annona muricata leaves induced apoptosis in A549 cells through mitochondrial-mediated pathway and involvement of NF-KB
}

Soheil Zorofchian Moghadamtousi ${ }^{1}$, Habsah Abdul Kadir ${ }^{*}$, Mohammadjavad Paydar $^{2}$, Elham Rouhollahi ${ }^{2}$ and Hamed Karimian ${ }^{3}$

\begin{abstract}
Background: Annona muricata leaves have been reported to have antiproliferative effects against various cancer cell lines. However, the detailed mechanism has yet to be defined. The current study was designed to evaluate the molecular mechanisms of A. muricata leaves ethyl acetate extract (AMEAE) against lung cancer A549 cells.

Methods: The effect of AMEAE on cell proliferation of different cell lines was analyzed by MTT assay. High content screening (HCS) was applied to investigate the suppression of NF-KB translocation, cell membrane permeability, mitochondrial membrane potential (MMP) and cytochrome $c$ translocation from mitochondria to cytosol. Reactive oxygen species (ROS) formation, lactate dehydrogenase (LDH) release and activation of caspase-3/7, -8 and -9 were measured while treatment. The western blot analysis also carried out to determine the protein expression of cleaved caspase-3 and -9. Flow cytometry analysis was used to determine the cell cycle distribution and phosphatidylserine externalization. Quantitative PCR analysis was performed to measure the gene expression of Bax and BCl-2 proteins.

Results: Cell viability analysis revealed the selective cytotoxic effect of AMEAE towards lung cancer cells, A549, with an $I C_{50}$ value of $5.09 \pm 0.41 \mu \mathrm{g} / \mathrm{mL}$ after $72 \mathrm{~h}$ of treatment. Significant LDH leakage and phosphatidylserine externalization were observed in AMEAE treated cells by fluorescence analysis. Treatment of A549 cells with AMEAE significantly elevated ROS formation, followed by attenuation of MMP via upregulation of Bax and downregulation of BCl-2, accompanied by cytochrome $c$ release to the cytosol. The incubation of A549 cells with superoxide dismutase and catalase significantly attenuated the cytotoxicity caused by AMEAE, indicating that intracellular ROS plays a pivotal role in cell death. The released cytochrome $c$ triggered the activation of caspase-9 followed by caspase-3. In addition, AMEAE-induced apoptosis was accompanied by cell cycle arrest at $G_{0} / G_{1}$ phase. Moreover, AMEAE suppressed the induced translocation of NF-KB from cytoplasm to nucleus.
\end{abstract}

Conclusions: Our data showed for the first time that the ethyl acetate extract of Annona muricata inhibited the proliferation of A549 cells, leading to cell cycle arrest and programmed cell death through activation of the mitochondrial-mediated signaling pathway with the involvement of the NF-kB signalling pathway.

Keywords: Annona muricata, Lung cancer, Apoptosis, Caspase, Mitochondria, NF-kB

\footnotetext{
* Correspondence: habsah@um.edu.my

'Biomolecular Research Group, Biochemistry Program, Institute of Biological

Sciences, Faculty of Science, University of Malaya, Kuala Lumpur, Malaysia

Full list of author information is available at the end of the article
} 


\section{Background}

Lung cancer as one of the critical causes of cancer death throughout the world has the prevalent complication of apoptosis resistance against different anticancer agents [1]. Due to the typical asymptomatic progression of lung cancer at an early stage, it is normally diagnosed at an advanced stage (56\%). In spite of all the development in chemoradiation and surgical techniques, the 5-year survival rate for patients with advanced stage disease is still $3.6 \%$ [2]. In addition, numerous lung cancer survivors suffer from lung dysfunction, particularly patients with the lung surgical history [3]. Thereby, continued research into the development of safe and efficient new anticancer agents against lung cancer cells is urgently necessary for further improvements in cancer therapy.

Apoptosis is a critical physiological process responsible for the homeostatic mechanism and maintenance of cell populations in tissues [4]. Due to the close correlation between the mechanism of apoptosis and the effect of anticancer agents, extensive research has been done on this mode of cell death [5]. The accumulation of reactive oxygen species (ROS) in cancer cells is a critical factor for the induction of apoptosis by natural products [6,7], since it will result in oxidative DNA damage following by a collapse in mitochondrial membrane potential (MMP) and leakage of cytochrome $c$, which lead to the activation of the caspase cascade [8]. Furthermore, the perturbation in the expression level of Bax and Blc-2 proteins is an important factor to determine the susceptibility of tumor cells to anticancer agents [9]. Previous anticancer studies also proved that constitutive activation of the ubiquitous transcription factor of NF- $\mathrm{kB}$ (nuclear factor-kappa B) is involved in governing the promoting tumor progression of solid and hemopoietic malignancies $[10,11]$. Therefore, anticancer agents with the ability to suppress the NF- $\mathrm{kB}$ translocation are effectively induce the apoptosis in cancer cells.

Annona muricata L. known as gravel, guanabana and soursop is a member of Custard-Apple plants in the Annonaceae family due to a custard-like texture of its fruit. It is a small deciduous tree with a height of 5-8 m and roundish canopy [12]. This popular fruit tree has been widely cultivated in many tropical countries and traditionally used for an array of diseases and ailments [13]. Previous studies demonstrated a significant cytotoxicity for $A$. muricata leaves against various cancer cell lines without affecting the normal cells $[14,15]$. Due to this tremendous antiproliferative effect, $A$. muricata was described as "the cancer killer" [15]. Ethanolic extract of A. muricata leaves was suggested to have apoptosisinducing potential against myelogenous leukemic K562 cells, although the detailed mechanism of action has not been explained [16]. Amongst constituents isolated from A. muricata leaves, namely annonaceous acetogenins, alkaloids and essential oils, annonaceous acetogenins are strongly implied to be responsible for the promising anticancer effect [17]. The principle objective of this study was to examine how A. muricata leaves affecting A549 lung cancer cells, and to investigate the possible mechanism of action involved in this effect.

\section{Methods}

\section{Plant material and extraction procedures}

The plant species (Annona muricata) collected from Ipoh, Malaysia, was authenticated by Dr. Yong Kien Thai, an ethnobotanist from the department of Biological Sciences, University of Malaya. The voucher specimen number for this plant is KLU47978. The air-dried leaves of $A$. muricata $(1 \mathrm{~kg})$ were cut into fine pieces using a mill grinder and soaked in $\mathrm{n}$-hexane $(1500 \mathrm{~mL}$, three times) in conical flasks for four days at room temperature $\left(25-27^{\circ} \mathrm{C}\right)$. The $\mathrm{n}$-hexane extract was filtered and the residues were sequentially re-extracted with ethyl acetate $(1500 \mathrm{ml}$, three times) and methanol (1500 ml, three times) using the same method. The resultant filtrate was concentrated to dryness by a Buchi R110 Rotavapor (Buchi Labortechnik AG, Flawil, Switzerland) at $40^{\circ} \mathrm{C}$ and stored at $-30^{\circ} \mathrm{C}$ until use. The isolated extracts were dissolved in dimethyl sulfoxide (DMSO) for further experiments.

\section{Cell culture and MTT assay}

MCF-7 (human breast cancer cells), MDA-MB-231 (human breast cancer cells), A549 (human lung cancer cells), HepG2 (human hepatoma cells) and WRL-68 (human hepatic cells) cell lines were obtained from American Type Cell Collection (ATCC, Manassas, VA, USA). Cells were cultured in RPMI-1640 medium (Sigma, St. Louis, MO, USA) supplemented with 10\% FBS (PAA, Pasching, Austria), $100 \mathrm{U} / \mathrm{mL}$ penicillin (PAA) and $50 \mu \mathrm{g} / \mathrm{mL}$ amphotericin B (PAA) at $37^{\circ} \mathrm{C}$ with $5 \% \mathrm{CO}_{2}$. The negative control for all the assays was represented by the untreated medium containing vehicle DMSO (0.1\%).

The cytotoxicity of the extracts was determined using the MTT assay as originally described by Mossman [18]. Briefly, cells were treated with different concentrations $(1.56,3.12,6.25,12.5,25,50$ and $100 \mu \mathrm{g} / \mathrm{mL})$ of three isolated extracts (hexane, ethyl acetate and methanol) and curcumin (positive control) in 96-well plates and incubated for $72 \mathrm{~h}$. After the incubation time, MTT dye ( $20 \mu \mathrm{L}, 5 \mathrm{mg} / \mathrm{mL}$, Sigma) was added to the cells for $4 \mathrm{~h}$ followed by incubation with DMSO for $10 \mathrm{~min}$. The colorimetric assay was measured at the absorbance of $570 \mathrm{~nm}$ using a microplate reader (Asys UVM340, Eugendorf, Austria). The antiproliferative potential of the extracts was expressed as $\mathrm{IC}_{50}$ values. As an ethyl acetate extract of the leaves (AMEAE) demonstrated the lowest $\mathrm{IC}_{50}$ value against lung cancer A549 cells, 
we used only AMEAE to continue this study against A549 cells.

\section{$\mathrm{LDH}$ release assay}

To confirm the cytotoxicity of AMEAE, we carried out lactate dehydrogenase (LDH) release assay using Pierce ${ }^{\text {tx }} \mathrm{LDH}$ Cytotoxicity Assay Kit (Thermo Scientific ${ }^{\text {rnt }}$, Pittsburgh, PA, USA). In brief, A549 cells were treated with AMEAE at different concentrations for $48 \mathrm{~h}$. The supernatant of treated A549 cells was transferred into 96-well plate to assess the LDH activity. Triton X-100 (2\%) served as a positive control was used to completely lyse the cells and release the maximum LDH. Next, the LDH reaction solution $(100 \mu \mathrm{l})$ was added to the cells for $30 \mathrm{~min}$. The red color intensity presenting the LDH activity was measured by the absorbance at 490 using a Tecan Infinite 200 Pro (Tecan, Männedorf, Switzerland) microplate reader. The level of released LDH from treated cells was expressed as a percentage of positive control.

\section{Acridine orange/propidium iodide (AO/PI) double staining assay}

Morphological changes induced by AMEAE in A549 cells were analyzed using Acridine orange/Propidium iodide (AO/PI) double staining assay. Briefly, A549 cells were seeded in $60 \mathrm{~mm}^{2}$ culture dishes followed by treatment with AMEAE $(10 \mu \mathrm{g} / \mathrm{mL})$ for 24,48 and $72 \mathrm{~h}$. After the incubation time, extract-untreated and treated A549 cells were harvested and washed with PBS. Then, the pellets were stained with $10 \mu \mathrm{g} / \mathrm{mL}$ of $\mathrm{AO} / \mathrm{PI}(1 \mathrm{mg} / \mathrm{mL})$. The stained cells were then observed under a BX51 UVfluorescent microscope (Olympus, Tokyo, Japan) within $30 \mathrm{~min}$.

\section{Annexin-V-FITC assay}

Induction of the early and late apoptosis by AMEAE was further studied via Annexin-V/PI staining assay. Briefly, A549 cells $\left(1 \times 10^{6}\right)$ were plated in $60 \mathrm{~mm}^{2}$ culture dishes and treated with vehicle DMSO and AMEAE $(10 \mu \mathrm{g} / \mathrm{mL})$ for 24, 48 and $72 \mathrm{~h}$. After harvest of adherent and suspension cells and washing them twice with PBS, they were resuspended in Annexin- $\mathrm{V}$ binding buffer (BD Biosciences, San Jose, CA, USA) and stained with Annexin-V-FITC (BD) and PI (Sigma) according to the manufacturer's instructions. The fluorescence intensity of A549 cells was then analyzed by flow cytometry (BD FACSCanto ${ }^{\mathrm{Tm}}$ II, San Jose, CA, USA) through quadrant statistics for necrotic and apoptotic cell populations. PI was used for detection of the late apoptosis and necrosis while Annexin- $\mathrm{V}$ was consumed for the detection of the early and late apoptosis.

\section{Cell cycle assay}

A flow cytometry analysis was carried out to determine the cell cycle distribution in treated A549 cells with
AMEAE. In brief, A549 cells $\left(5 \times 10^{4}\right.$ cells $\left./ \mathrm{mL}\right)$ were treated with AMEAE $(10 \mu \mathrm{g} / \mathrm{mL})$ for 24,48 and $72 \mathrm{~h}$. After fixation with cold ethanol, cells were washed with PBS and stained with PI $(50 \mu \mathrm{l}, 10 \mathrm{mg} / \mathrm{mL})$ for $1 \mathrm{~h}$ at $37^{\circ} \mathrm{C}$. In addition, RNase A $(10 \mathrm{mg} / \mathrm{mL})$ was also used to limit the ability of the PI to bind only to DNA molecules. The stained cells were analyzed for DNA content using flow cytometer (BD FACSCanto ${ }^{\text {Tw }}$ II).

\section{Reactive oxygen species (ROS) assay}

The effect of AMEAE on the ROS formation in A549 cells was determined by ROS assay. Briefly, treated lung cancer cells with AMEAE at different concentrations in 96-well plates were incubated for $24 \mathrm{~h}$. After the incubation time, the treated cells were stained with dihydroethidium (DEH) at $2.5 \mu \mathrm{g} / \mathrm{mL}$ and Hoechst 33342 $(500 \mathrm{nM})$ dyes for $30 \mathrm{~min}$. Then, cells were fixed with paraformaldehyde (3.5\%) for $15 \mathrm{~min}$ and washed with PBS twice. The Cellomics ArrayScan HCS reader was used to measure the ROS generation in treated A549 cells.

To further determine the role of ROS generation in AMEAE-induced antiproliferative effect, A549 cells were treated with antioxidants prior to treatment with AMEAE and the cell viability was measured after $24 \mathrm{~h}$. In brief, A549 cells in the exponential phase of growth were supplemented with antioxidants superoxide dismutase (SOD, $300 \mathrm{U} / \mathrm{mL}$ ) and catalase $(400 \mathrm{U} / \mathrm{mL})$ for $1 \mathrm{~h}$ prior to AMEAE $(20 \mu \mathrm{g} / \mathrm{mL})$ treatment for $24 \mathrm{~h}$. After incubation time, the cell viability analysis was carried out using a microplate reader (Asys UVM340, Eugendorf, Austria).

\section{Multiple cytotoxicity assay}

To simultaneously determine the crucial apoptotic events in A549 cells after treatment with AMEAE, we used Cellomics Multiparameter Cytotoxicity 3 Kit (Thermo Scientific ${ }^{\mathrm{Tx}}$, Pittsburgh, PA, USA). Briefly, lung cancer A549 cells were seeded into 96-well plates for $24 \mathrm{~h}$. The cells were treated with AMEAE at different concentrations prior to staining the cells with cell permeability and mitochondrial membrane potential (MMP) dyes. Then, cells were fixed and blocked with $1 \mathrm{X}$ blocking buffer according to the manufacture's protocol. Next, primary cytochrome $c$ antibody and secondary DyLight 649 conjugated goat antimouse IgG were added for $1 \mathrm{~h}$. Nuclei of treated cells were also stained with Hoechst 33342 dye. Stained A549 cells in 96-well plates were analyzed using ArrayScan high content screening (HCS) system.

\section{Bioluminescent assays for caspase- $8,-9$ and $-3 / 7$ activities}

A dose-dependent study on the caspase- $8,-9$ and $-3 / 7$ activation was carried out using Caspase-Glo $3 / 7,8$ and 9 kit (Promega, Madison, WI, USA). In brief, a total of 
$5 \times 10^{3}$ A549 cells were seeded per well in a white 96well microplate and incubated with different concentrations of AMEAE for $24 \mathrm{~h}$. Then, caspase-Glo reagent $(100 \mu \mathrm{l})$ was added to the cells for $30 \mathrm{~min}$. The induced activation of caspases was measured using a Tecan Infinite 200 Pro (Tecan, Männedorf, Switzerland) microplate reader.

To determine the protein expression of cleaved caspase3 and -9 , western blot analysis was carried out as previously described in detail [19]. In brief, A549 cells treated with vehicle DMSO or AMEAE at different concentrations were washed with PBS and lysed in ice-cold Radio Immuno Precipitation Assay (RIPA) buffer. Cell extracts (80 $\mu \mathrm{g}$ protein) were subjected to sodium dodecyl sulfatepolyacrylamide gel electrophoresis (SDS-PAGE), transferred to nitrocellulose membrane, probed with anti$\beta$-actin, anti-cleaved caspase- 9 and anti-cleaved caspase- 3 (Cell Signaling Technology, Danvers, MA, USA). HRPconjugated secondary antibodies were used followed by the detection of protein expression using the ECL plus chemiluminescence kit (Amersham Biosciences, Piscataway, NJ, USA).

\section{Quantitative PCR analysis}

The expression of the Bax and Bcl-2 in treated A549 cells was analyzed by quantitative PCR analysis. After treatment of A549 cells with the AMEAE extract at different concentrations for $24 \mathrm{~h}$, Zymo Research Quick-RNA ${ }^{\mathrm{mm}}$ MiniPrep kit (Zymo Research, Freiburg, Germany) was used to isolate total RNAs according to the manufacture's protocol. Then, High Capacity RNA-to-cDNA ${ }^{\mathrm{m}}$ kit (Applied Biosystems, Foster City, CA, USA) was used to synthesize complementary DNAs. Quantitative PCR was carried out with TaqMan ${ }^{\circledR}$ Gene Expression Assays and TaqMan ${ }^{\odot}$ Fast Advanced Master Mix using the Applied Biosystems StepOnePlus ${ }^{\mathrm{Tm}}$ system. GAPDH was used to normalize all data. The IDs for TaqMan ${ }^{\odot}$ Gene Expression Assays used in this study are GAPDH: Hs02758991_g1, Bcl-2: Hs00608023_m1 and Bax: Hs00180269_m1.

\section{Measurement of NF-KB activity}

The Cellomics ArrayScan HCS system was used to analyze the suppressive effect of AMEAE on the nuclear translocation of NF- $\mathrm{kB}$ induced by TNF- $\alpha$. The experiment was carried out using Cellomics nucleus factor $-\kappa B$ (NF-kB) activation kit (Thermo Scientific) as previously described [20]. In brief, A549 cells $\left(1.0 \times 10^{4}\right.$ cells/well $)$ were treated with AMEAE at different concentrations in a 96-well plate for $3 \mathrm{~h}$. The treated A549 cells were stimulated by TNF- $\alpha$ ( $1 \mathrm{ng} / \mathrm{mL})$ for $30 \mathrm{~min}$. Then, cells were fixed and stained according to the manufacturer's protocol and analyzed using Array Scan HCS Reader and Cytoplasm to Nucleus Translocation Bioapplication software.

\section{Statistical analysis}

Data are presented as mean \pm SEM of three individual experiments. Statistical analysis was performed with a one-way ANOVA analysis using the Prism statistical software package (GraphPad Software, USA). Differences were considered as being significant at ${ }^{*} p<0.05$.

\section{Results and discussion}

\section{AMEAE inhibited the proliferation of cancer cells}

We first examined the cytotoxic effect of three extracts (hexane, ethyl acetate and methanol) against MCF-7 (human breast cancer cells), MDA-MB-231 (human breast cancer cells), A549 (human lung cancer cells), HepG2 (human hepatoma cells) and WRL-68 (human hepatic cells) cell lines by using MTT assay. Treatment with AMEAE for $72 \mathrm{~h}$ significantly reduced the cell proliferation in cancer cells. As shown in Table 1, the results showed the significant cytotoxic activity of ethyl acetate extract towards all cancer cells. The ethyl acetate extract $\left(\mathrm{IC}_{50}\right.$ ranged from $5.09 \pm 0.41$ to $\left.11.36 \pm 0.67 \mu \mathrm{g} / \mathrm{mL}\right)$ showed the highest cytotoxicity against all cancer cells as compared to others. Furthermore, the ethyl acetate extract exhibited the highest cytotoxic activity towards A549 cells with the $\mathrm{IC}_{50}$ of $5.09 \pm 0.41$ compared to $11.32 \pm 1.54$ for the positive control curcumin. After 24 and $48 \mathrm{~h}$ treatment with AMEAE, A549 cells elicited the $\mathrm{IC}_{50}$ values of $17.542 \pm 0.92$ and $10.612 \pm 1.34 \mu \mathrm{g} / \mathrm{mL}$. It is worth noting that normal human hepatic WRL-68 cells were not noticeably affected by AMEAE treatment. The cell viability results suggested that the AMEAE inhibitory effect is selective for cancer cells.

\section{Induction of $\mathrm{LDH}$ release by AMEAE}

A stable cytosolic enzyme of lactate dehydrogenase (LDH) catalyzes the oxidation of L-lactate to pyruvate. Upon membrane damage in cells, $\mathrm{LDH}$ enzyme is released into the culture medium, suggesting the loss of membrane integrity [21]. Therefore, to further confirm the cytotoxic effect of AMEAE on A549 cells, LDH assay was also performed as another indicator of A549 cytotoxicity. As shown in Figure 1, LDH leakage of A549 cells was significantly increased with the presence of AMEAE by 5.9 folds.

\section{Quantification of apoptosis using fluorescence microscope and AO/PI double-staining}

Energy-dependent biochemical pathways and distinct morphological features are the main characteristics of apoptosis, or programmed cell death. During the early apoptosis, pyknosis and cell shrinkage are characterized in apoptotic cells [22]. Cell shrinkage is a result of condensation of organelles and the density of cytoplasm, and chromatin condensation or pyknosis is the most critical feature of early apoptosis [23]. The process of 
Table $1 \mathrm{IC}_{50}$ values of $A$. muricata leaves extracts on five different cell lines after $\mathbf{7 2} \mathrm{h}$ treatment

\begin{tabular}{llllll}
\hline Extract & \multicolumn{3}{c}{} & IC $_{\mathbf{5 0}}(\boldsymbol{\mu} \mathbf{g} / \mathbf{m L})$ & \\
\cline { 2 - 5 } & MCF-7 & MDA-MB-231 & A549 & HepG2 & WRL-68 \\
\hline Hexane & $49.92 \pm 2.23$ & $38.72 \pm 0.99$ & $21.05 \pm 0.42$ & $77.92 \pm 2.23$ & $89.53 \pm 3.93$ \\
Ethyl acetate & $6.39 \pm 0.43$ & $11.36 \pm 0.67$ & $5.09 \pm 0.41$ & $9.3 \pm 0.91$ & $47.10 \pm 1.23$ \\
Methanol & $85.58 \pm 3.55$ & $>100 *$ & $>100$ & $>100$ & $>100$ \\
Curcumin & $7.65 \pm 0.55$ & $9.34 \pm 0.76$ & $11.32 \pm 1.54$ & $17.66 \pm 1.21$ & $54.24 \pm 2.21$ \\
\hline
\end{tabular}

The data represent the means \pm SEM of three independent experiments.

* $>100$ represents the $I C_{50}$ values greater than $100 \mu \mathrm{g} / \mathrm{mL}$.

late apoptosis is accompanied by budding which contains extensive blebbing of plasma membrane with tightly packed organelles [24]. In the present study, AMEAE was examined for its apoptotic-inducing activity by fluorescence microscopy analysis. Morphological changes in control and treated A549 cells were observed after treatment with AMEAE at 24, 48 and $72 \mathrm{~h}$. It is noteworthy that at $72 \mathrm{~h}$ the control cells remained intact and displayed normal structures with a green intact nuclear structure (Figure 2A). After $24 \mathrm{~h}$ of treatment, clear signs of apoptosis, such as cytoplasmic shrinkage and membrane blebbing, were observed at a treatment concentration of $10 \mu \mathrm{g} / \mathrm{mL}$. The early apoptotic cells were

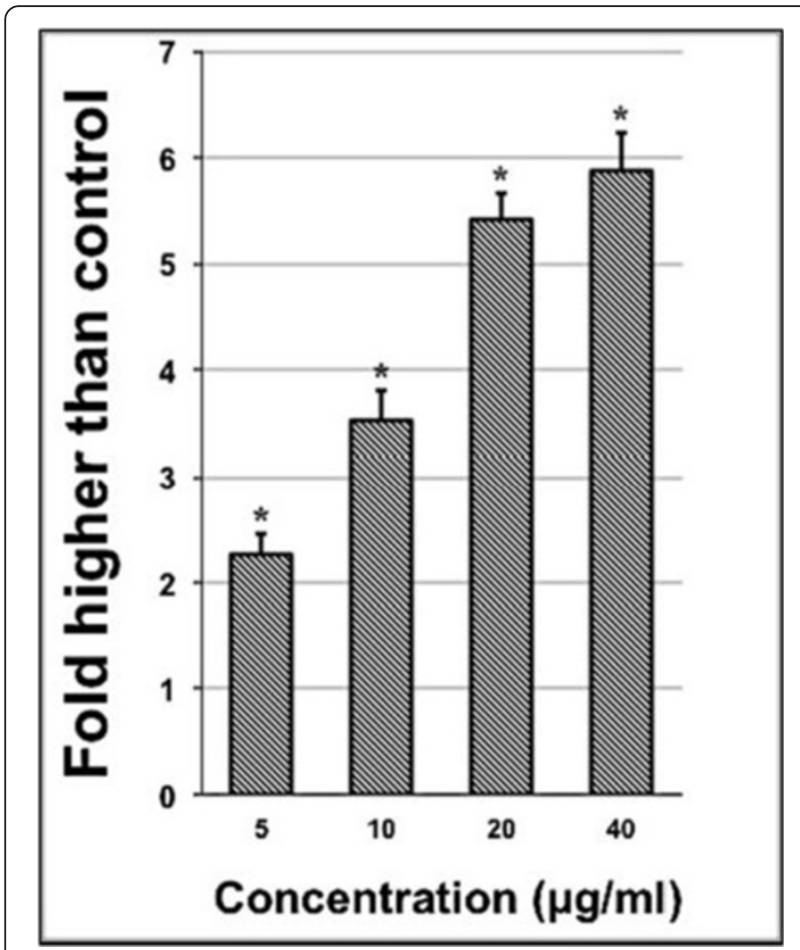

Figure 1 Lactate dehydrogenase (LDH) assay showed the cytotoxicity of AMEAE against A549 cells. The result revealed significant cytotoxicity at concentrations of 5 to $40 \mu \mathrm{g} / \mathrm{mL}$, in a dose-dependent manner. The data represent the means \pm SEM of three independent experiments. ${ }^{*} p<0.05$ compared with the untreated group detected via the binding of $\mathrm{AO}$ within the fragmented DNA emanating a bright green fluorescence. At $24 \mathrm{~h}$ treatment with AMEAE, moderate apoptosis was seen by nuclear chromatin condensation and blebbing (Figure 2B). In addition, the late stages of apoptosis as indicated by changes such as the presence of a reddish-orange color because of the binding of PI to denatured DNA were observed after 48 and $72 \mathrm{~h}$ of treatment (Figure $2 \mathrm{C}$ and D). The results showed that AMEAE generated morphological features that are associated with apoptosis in a time-dependent manner.

\section{Induction of early and late apoptosis using flow cytometry analysis}

Our investigations thus far revealed the typical morphological features of apoptosis in AMEAE-treated A549 cells. The morphological changes in apoptotic cells are accompanied by several biochemical modifications, including DNA breakdown, protein cross-linking and protein cleavage which lead to the phagocytic recognition of apoptotic cells by adjacent cells [25]. One such biochemical modification is the expression of cell surface markers such as inward-facing phosphatidylserine which translocates to the outer side of plasma membrane during the early apoptosis [26]. To investigate the biochemical characterization of apoptosis, we examined the externalization of phosphatidylserine (PS) in A549 cells by Annexin-V-FITC assay. Annexin- $\mathrm{V}$ as a recombinant phosphatidylserine-binding protein with a high affinity for externalized PS is used for detection of early apoptosis [27]. PI was used for detection of the late apoptosis and necrosis, while Annexin- $\mathrm{V}$ was for the detection of the early and late apoptosis. Accordingly, to evaluate whether A549 cells undergo apoptosis, untreated and AMEAE-treated cells were stained with Annexin-V and PI. Flow cytometry analysis of stained cells can distinguish the cells into four categories, namely viable (Annexin-V and PI negative), early apoptosis (Annexin-V positive, PI negative), late apoptosis (Annexin-V and PI positive) and necrotic (Annexin-V negative, PI positive) cells. As illustrated in Figure 3, AMEAE treatment at different time periods $(24,48$ and $72 \mathrm{~h}$ ) resulted in a timedependent increment of early apoptotic and late apoptotic 
A

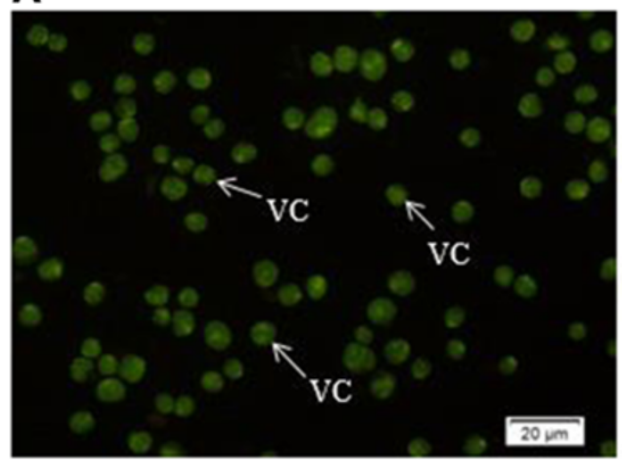

C

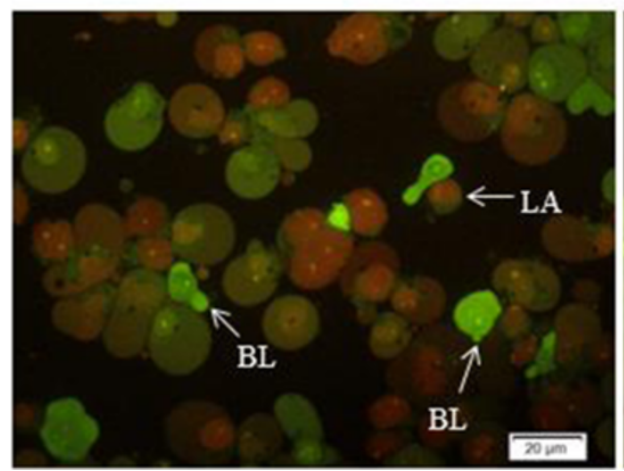

B

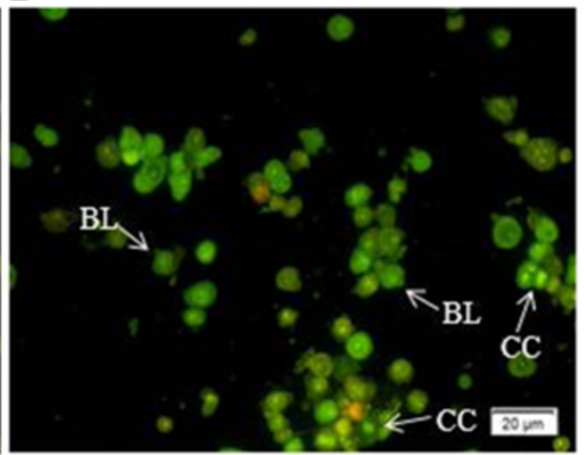

D

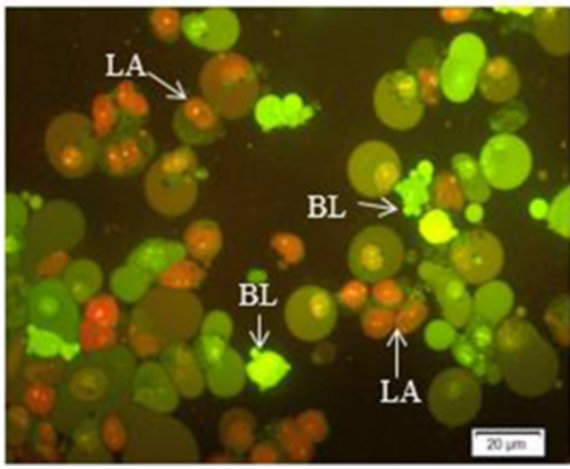

Figure 2 Fluorescent micrographs of AO/PI-double-stained A549 cells. (A) Untreated A549 cells after 72 h depict healthy structures. Early apoptosis features such as chromatin condensation and blebbing were observed after (B) 24, (C) 48 and 72 h (D) of treatment with AMEAE. Late apoptosis was observed at the late stage of treatment (magnification: 200X). VC: Viable cells; CC: Chromatin condensation; BL: Blebbing of the cell membrane; LA: Late apoptosis.

populations which peaked at $34.1 \%$ and $42.6 \%$, respectively, after $72 \mathrm{~h}$ treatment.

\section{AMEAE-induced $G_{1}$ cell cycle arrest}

Cancer is often considered as a disease of cell cycle deregulation. Cell size, extracellular growth signals and DNA integrity are tightly regulated by multiple checkpoints in cell cycle progression [28]. Cancer can originate from perturbation in the expression of positive or negative regulators of cell cycle machinery leading to abnormal proliferation of cancer cells [29]. Thus, induction of cell cycle arrest in cancer cells is considered to be one of the crucial cancer treatment strategies. Phytochemicals with the ability to modulate the cell cycle progression are gaining extensive attention because of the supporting evidences of the concomitant involvement of cell cycle suppression and apoptosis [30,31]. Thus, flow cytometry analysis was performed to evaluate the effect of AMEAE on the DNA content at various cell cycle checkpoints of A549 cells by cell cycle phase distribution $\left(G_{0}, G_{1}, S, G_{2}\right.$ and $\left.M\right)$ after treatment for 24,48 and 72 h. As shown in Figure 4, there was a significant $G_{0} /$ $\mathrm{G}_{1}$ phase arrest in a time-dependent manner demonstrating that AMEAE arrested cell cycle progression at the $G_{0} / G_{1}$ phase (Figure 4). Moreover, the increase in the sub- $G_{1}$ phase confirms the apoptosis findings.

\section{ROS generation induced by AMEAE}

Reactive oxygen species are produced as the result of normal metabolism during the reduction of oxygen to water. Oxidative stress due to increase in the level of intracellular ROS leads to a variety of biochemical and physiological lesions following to metabolic impairments and cell death [32]. The stimulus of free radicals and oxidative stress can trigger the mitochondrial initiated events leading to the activation of intrinsic pathway [33]. Thus, there is an upsurge of interest in cancer studies to use this major role for induction of apoptosis in cancer cells. To investigate this association, the levels of intracellular ROS in A549 cells treated with AMEAE was examined by flow cytometry analysis. In the present study, it was found that AMEAE has noteworthy potential in the induction of ROS generation in A549 cells as shown in Figure 5. As a result of ROS generation, non-fluorescent dihydroethidium (DHE) convert to the fluorescent dye of ethidium, which can bind to DNA. A dose-dependent elevation in ethidium fluorescence in the nucleus was detected in treated A549 cells (Figure 5A). As shown in 


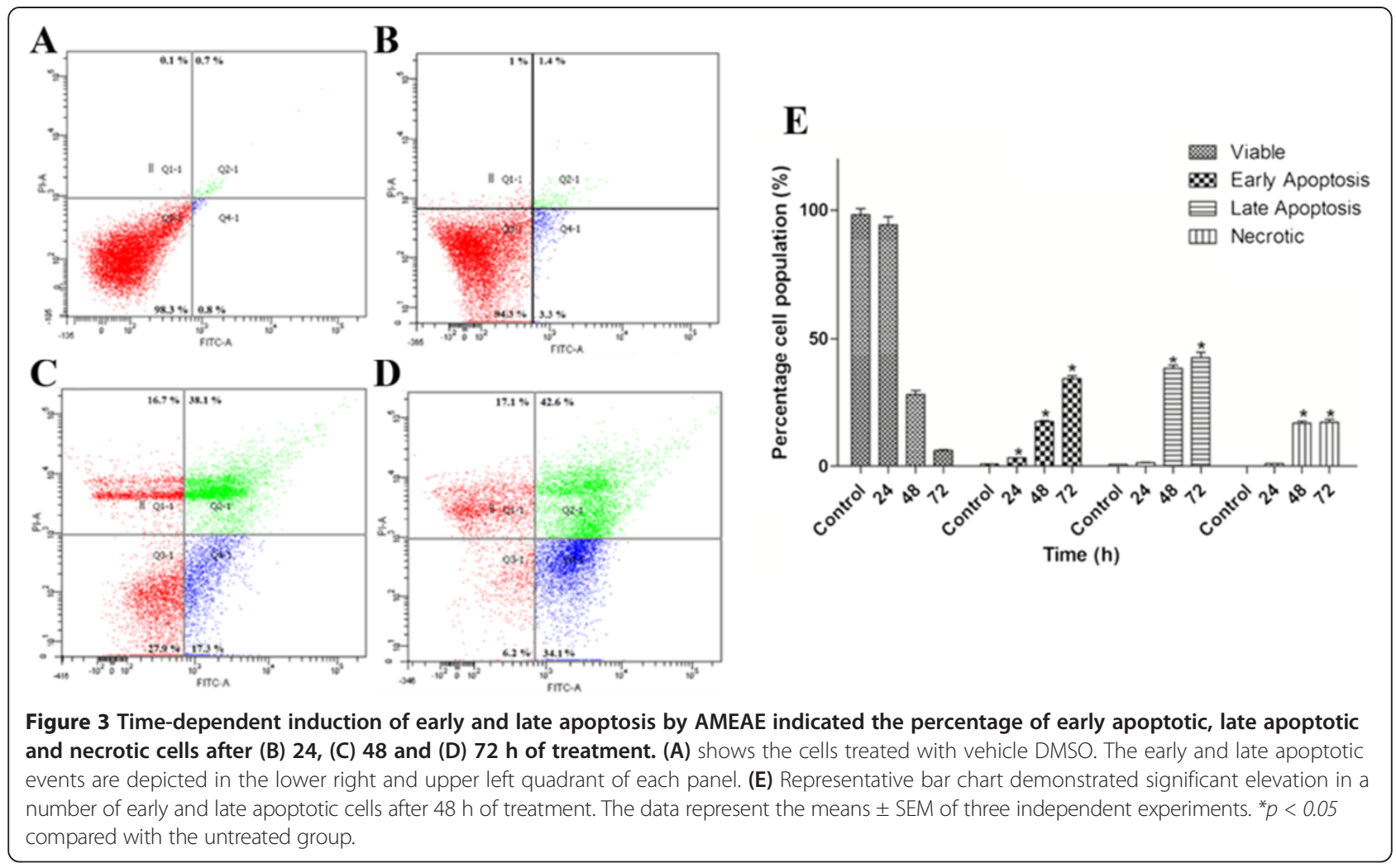

Figure 5B, ROS production was at the basal level in control untreated A549 cells. In contrast, treatment with AMEAE $(24 \mathrm{~h})$ resulted in dose-dependent increase of ROS production as shown by increased ethidium staining in the nucleus (Figure 5A and $\mathrm{B}$ ). However, pretreatment of A549 cells with antioxidants, namely SOD and Cat significantly increased the cell viability after $24 \mathrm{~h}$ compared to the treatment with AMEAE alone (Figure 5C). The viable cells was $62 \%$ and $78 \%$ by pretreatment with SOD and Cat, respectively, compared with only about $43 \%$ by treatment with AMEAE alone. This result supports the close correlation between ROS burst and cytotoxic effect of AMEAE, which suggests to be through activation of the mitonchondrial initiated events.

\section{Mitochondria-initiated events induced by AMEAE}

During apoptosis, mitochondrial membrane potential is frequently disrupted due to the formation of permeability transition pores or the insertions of proapoptotic proteins, such as, Bid or Bax in the mitochondrial membrane [34]. A variety of non-receptor mediated stimuli, including free radicals, radiation, hypoxia and toxin can trigger the intrinsic signaling pathway [26]. The stimuli produce intracellular signals that cause loss in MMP and the opening of the mitochondrial permeability transition pore. These changes in the inner mitochondrial membrane lead to the release of various proteins from the intermembrane space into the cytosol [35]. The main group of released proteins consists of serine protease HtrA2/Omi, cytochrome $c$ and Smac/DIABLO. Cytochrome $c$ forms apoptosome through binding to pro-caspase-9 as well as Apaf-1. Apoptosome activates caspase- 9 following with activation of caspase- 3 [36,37].

It is well established that extensive ROS production could result in the disruption of the plasma membrane and mitochondrial damage, thus we further examined the cell membrane permeability, MMP and cytochrome $c$ translocation [38]. To determine the function of mitochondria, we applied MMP fluorescent probe. As shown in Figure 6A, untreated A549 cells were strongly stained with red MMP dye, while treated A549 cells with AMEAE were not markedly stained after $24 \mathrm{~h}$. The dose-dependent reduction in fluorescence intensities of MMP was associated with significant elevation in cell membrane permeability which is shown by green fluorescence intensities in Figure 6A. Furthermore, AMEAE significantly elevated the translocation of cytochrome $c$ from mitochondria to cytosol in A549 cells after 24 h. In the treated A549 cells, the cyan fluorescence intensities of cytochrome $c$ dye (Figure 6A) were markedly increased presenting the significant cytochrome $c$ release from mitochondria. The present findings demonstrated that treatment with AMEAE revealed a concentration-dependent increase in membrane permeability, attenuation of MMP, and increase in cytochrome $c$ in the cytosol when compared to the control. 

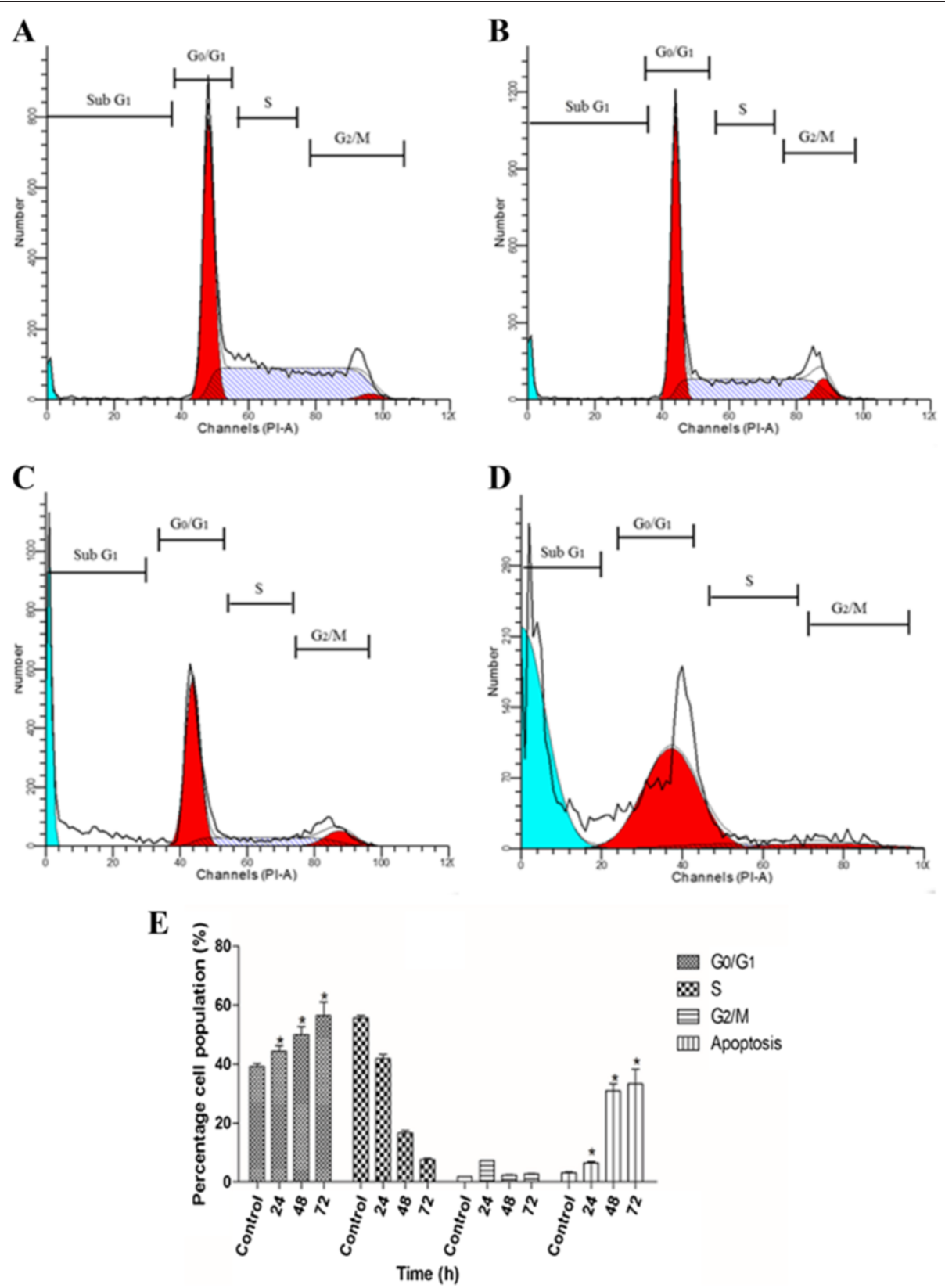

Figure 4 Flow cytometry analysis on cell cycle progression in A549 cells was carried out after incubation with AMEAE for (A) 0, (B) 24, (C) 48 and (D) 72 h. (E) Representative bar chart demonstrated significant cell cycle arrest at the $G_{1}$ phase. The data represent the means \pm SEM of three independent experiments. ${ }^{*} p<0.05$ compared with the no-treatment group.

AMEAE induced caspase- $8,-9$ and $-3 / 7$ activation

Caspase activation with proteolytic effect at aspartic acid residues are involved in an energy-dependent cascade of molecular events towards apoptosis. To date, two major groups of caspases have been identified to be involved in apoptosis pathways, including executioners or effectors (caspase-3, -6, -7) and initiators (caspase-2, -8, -9, -10) [36]. Intrinsic and extrinsic pathways are activated by their own initiator caspases, namely caspase- 9 and -8 , respectively. The activation of initiator caspases will, in turn, lead to activation of executioner caspases. The most critical of executioner caspases is considered to be caspase-3 [26]. The execution pathway leads to cytomorphological changes, namely chromatin condensation, cell shrinkage, formation of apoptotic bodies followed by phagocytosis of the apoptotic cell [39]. In the present study, we investigated whether AMEAE can activate the caspases by examining A549 cells treated with different concentrations for $24 \mathrm{~h}$. The activity of both caspase- 9 and caspase-3/7 were significantly elevated at 10, 20 and 


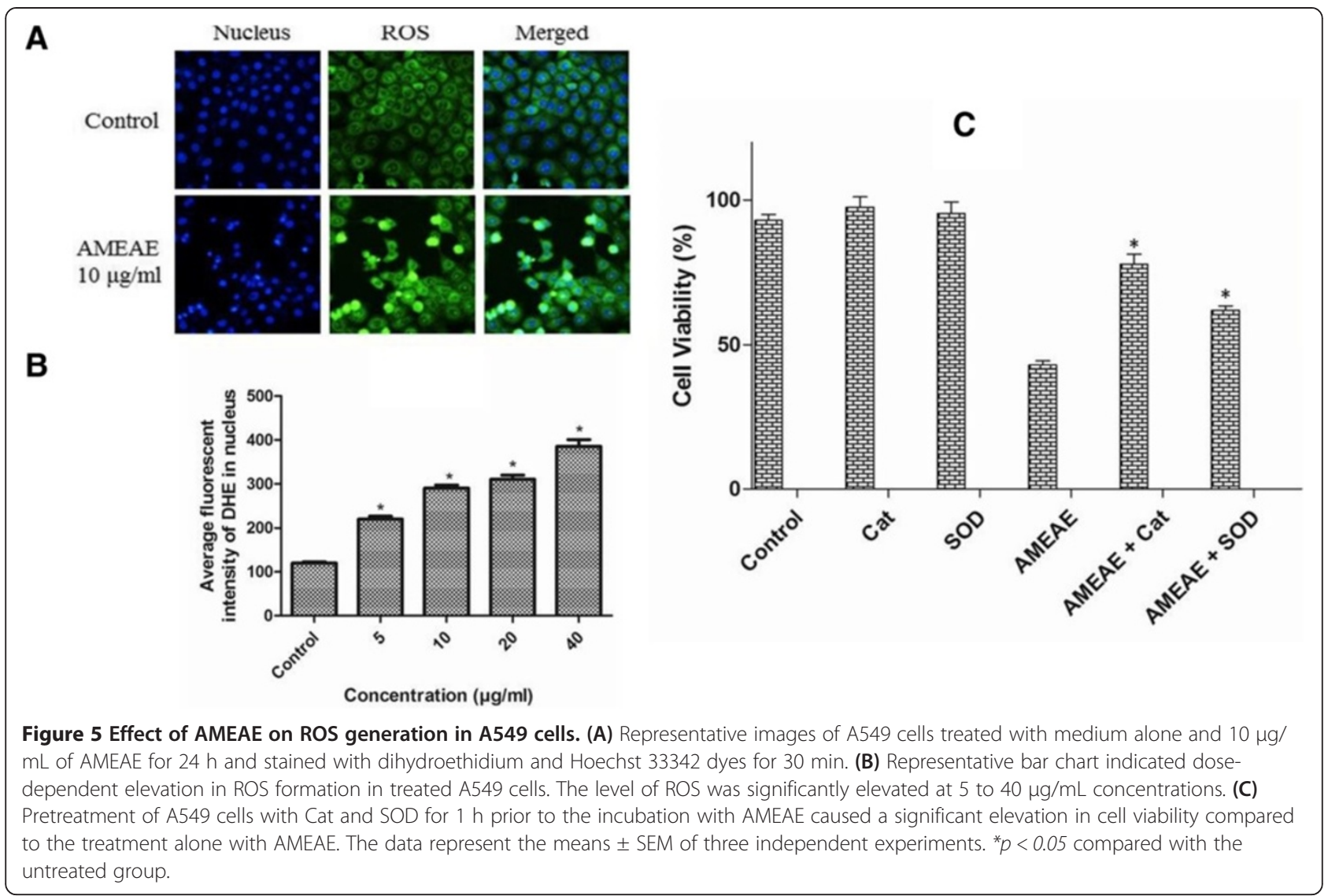

$40 \mu \mathrm{g} / \mathrm{mL}$ AMEAE treatment, while activation of caspase8 was only triggered at higher concentrations of 20 and $40 \mu \mathrm{g} / \mathrm{mL}$, suggesting that AMEAE induced apoptosis predominantly through mitochondrial-mediated intrinsic pathway (Figure 7). The western blot analysis of caspases also showed that the protein expression of cleaved caspase- 3 and -9 was dose-dependently increased upon treatment with AMEAE. The caspase-3 and -9 protein expressions were significantly up-regulated at 10 to $40 \mu \mathrm{g} / \mathrm{mL}$ concentrations. These results suggest the involvement of caspase cascade in AMEAE-mediated apoptosis.

\section{AMEAE induced upregulation of Bax and downregulation} of $\mathrm{BCl}-2$ at the gene expression level

The mitochondria-initiated events are tightly regulated by the Bcl-2 family of proteins, including pro-apoptotic and anti-apoptotic proteins. Progression and abortion of apoptosis are governed by 25 genes in this family of proteins [40]. The pro-apoptotic protein of Bax is involved in the cytochrome $c$ release from mitochondria to cytosol via dimerization and translocation to the outer mitochondrial membrane [41]. Meanwhile, anti-apoptotic proteins such as Bcl-2 suppress the translocation of cytochrome $c$ (5). The levels of both Bcl-2 and Bax mRNA expression were estimated by using quantitative PCR analysis. The results demonstrated that $\mathrm{Bcl}-2$ expression decreased significantly when A549 cells were treated with 20 and $40 \mu \mathrm{g} / \mathrm{mL}$ of AMEAE after $24 \mathrm{~h}$ as compared with the control cells (Figure 8). The expression of the proapoptotic Bax, however, increased significantly when treated with 20 and $40 \mu \mathrm{g} / \mathrm{mL}$ of AMEAE (Figure 8). Therefore, downregulation of $\mathrm{Bcl}-2$ and upregulation of Bax upon AMEAE treatment could lead to loss of MMP, which facilitated cytochrome $c$ release and activation of the caspase cascade. These changes in the gene expression of Bcl-2 and Bax confirmed the induction of apoptosis via mitochondrial-mediated intrinsic pathway.

\section{NF-кB translocation suppressed by AMEAE}

The ability of nuclear factor $-\kappa B(N F-k B)$ to inhibit the induction of apoptosis is considered to be involved in resistance against cytotoxic therapies. A variety of stimuli namely, anticancer agents and cellular stress can trigger NF- $\kappa \mathrm{B}$ activation, which has been linked to extrinsic signaling pathway and inducible chemoresistance [42]. Thus, suppression of NF- $\mathrm{kB}$ translocation in conjunction with chemotherapy can effectively elevate the effect of cancer therapy [43]. In this study, the ArrayScan HSC system was used to determine the role of AMEAE in the 


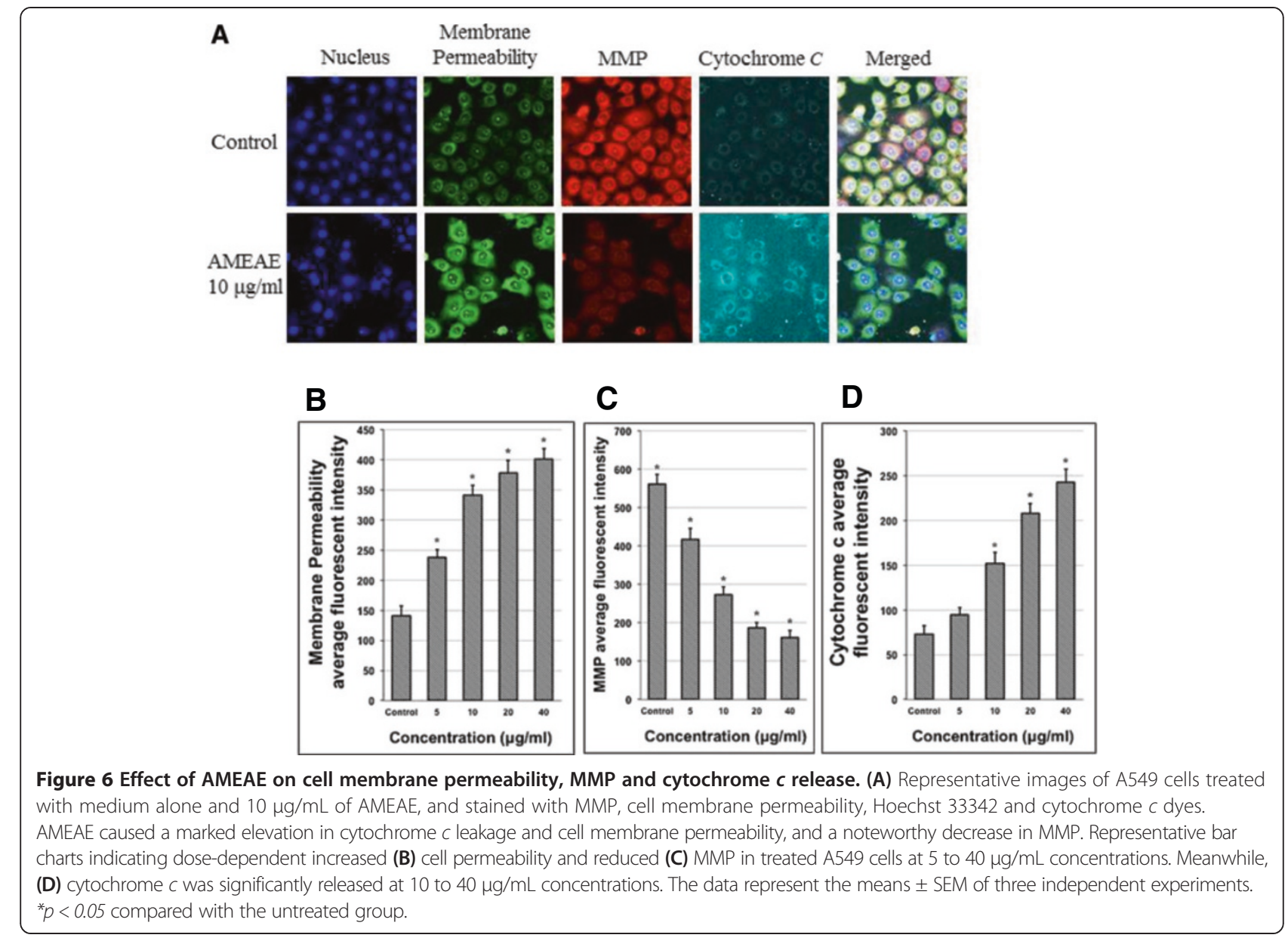

\section{A}

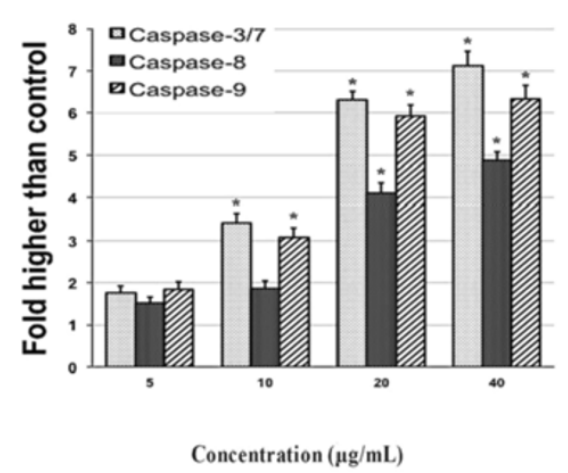

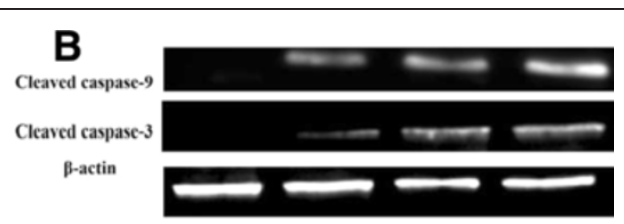

C

Control $\quad 10 \mu \mathrm{g} / \mathrm{ml} \quad 20 \mu \mathrm{g} / \mathrm{ml} \quad 40 \mu \mathrm{g} / \mathrm{ml}$

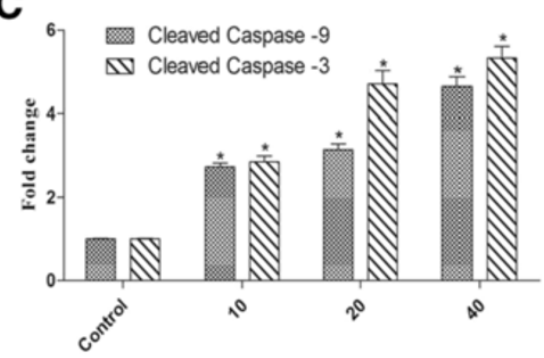

Concentration $(\mu \mathrm{g} / \mathrm{mL})$

Figure 7 Effect of AMEAE of caspases activation. (A) Relative luminescence dose-dependent activation of caspase-8, -9 and $-3 / 7$ in A549 cells treated with various concentrations of AMEAE. Caspase- 9 and $-3 / 7$ were significantly activated at 10 to $40 \mu \mathrm{g} / \mathrm{mL}$ concentrations. Meanwhile, caspase-8 was activated at higher concentrations (20 and $40 \mu \mathrm{g} / \mathrm{mL}$ ). (B) A549 cells were treated with the indicated concentrations of AMEAE for $24 \mathrm{~h}$. The cell lysates were evaluated for levels of cleaved caspase-3 and -9 . AMEAE induced the up-regulation of cleaved caspase-3 and -9.

(C) The quantitative analysis was expressed as a ratio to the expression of $\beta$-actin. The data represent the means \pm SEM of three independent experiments. ${ }^{*} p<0.05$ compared with the untreated group. 


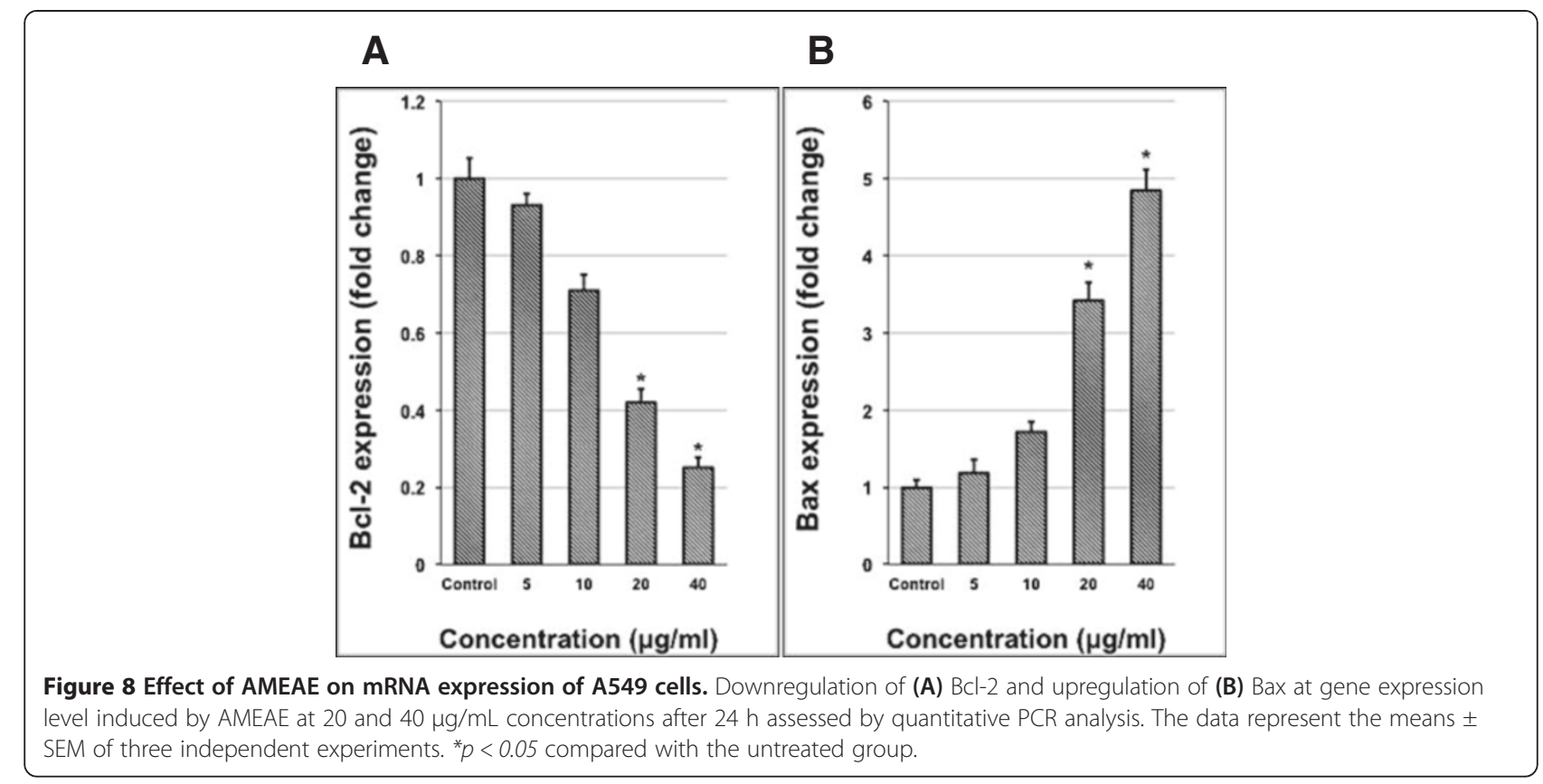

suppression of activated NF- $\kappa \mathrm{B}$. In control cells, a high NF- $k B$ fluorescence intensity was detected in the cytoplasm of A549 cells compared to the nuclei (Figure 9A). After treatment with AMEAE, nuclear NF-kB fluorescent intensity was dose-dependently reduced (Figure 9B). Stimulation of A549 cells by TNF- $\alpha$ resulted in a significant elevation in NF- $\mathrm{B}$ fluorescence intensity in the nuclei, while, A549 cells treated with AMEAE elicited significant suppressive effects on the activation of NF- $\mathrm{kB}$ (Figure 9A and B), at 10, 20 and $40 \mu \mathrm{g} / \mathrm{mL}$ in a concentration-dependent manner. The present findings demonstrated that AMEAE treatment can effectively reduce the activation of NF- $\mathrm{kB}$ signaling pathway in A549 cells. We have shown here that the NF-kB translocation can be suppressed by AMEAE, which suggests the involvement of an NF-kB inhibition mechanism in apoptosis.

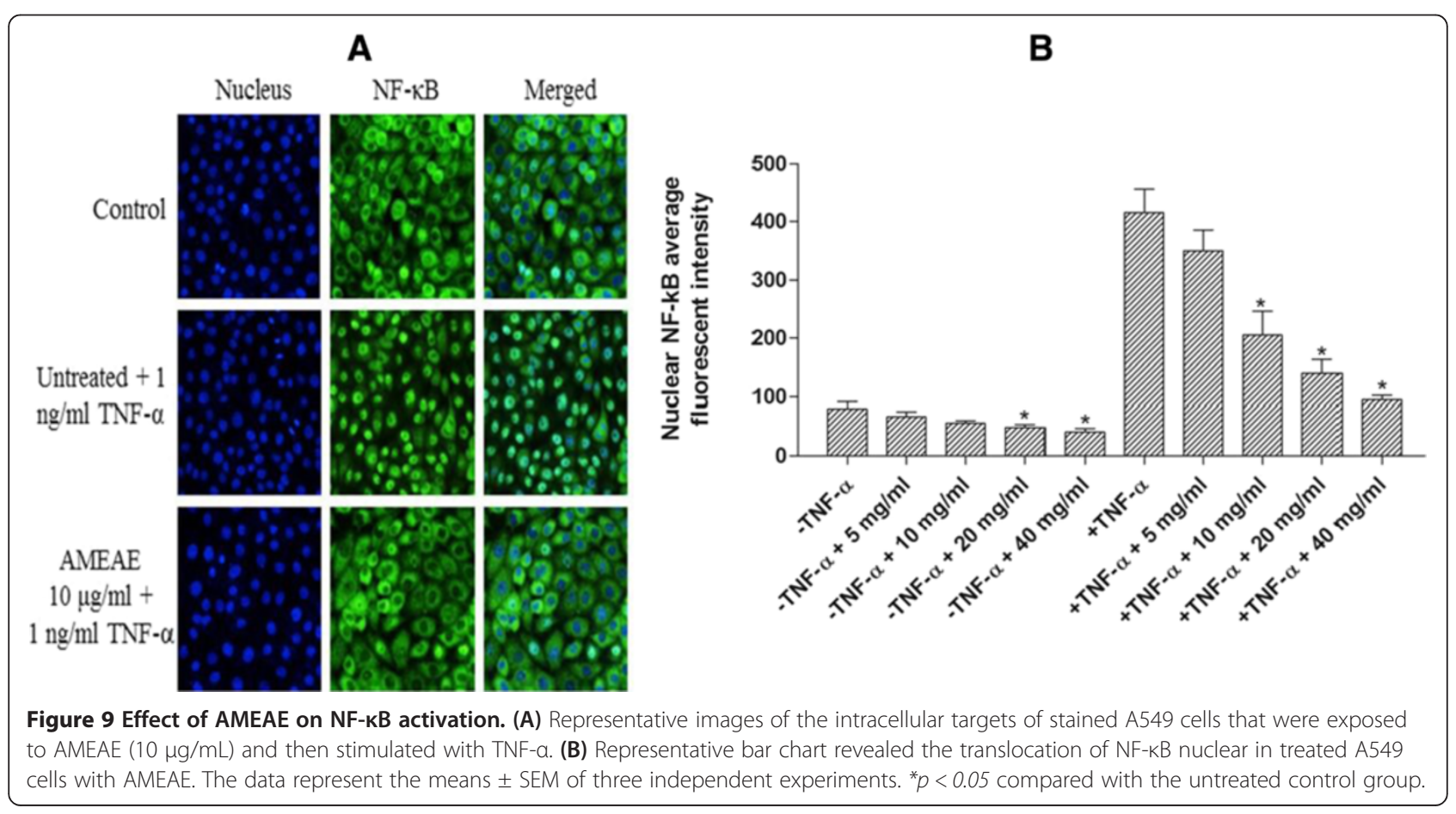




\section{Conclusions}

In conclusion, the anticancer potential of ethyl acetate extract of $A$. muricata leaves was supported by the evidence provided in the present study, including lactate dehydrogenase leakage, reactive oxygen species generation, loss in mitochondrial membrane potential, increase in the level of cytochrome $c$, upregulation of Bax, downregulation of Bcl-2 and activation of initiator and executioner caspases. The antiproliferative effect of AMEAE was accompanied by cell cycle arrest at $G_{1}$ phase and suppression of NF- $\mathrm{kB}$ translocation. The results confirmed the involvement of intrinsic pathways in induced apoptosis.

\section{Abbreviations}

AMEAE: A. muricata leaves ethyl acetate extract; HCS: High content screening; NF-kB: Nuclear factor-kappa B; MMP: Mitochondrial membrane potential; LDH: Lactate dehydrogenase; ROS: Reactive oxygen species (ROS); Bax: BCl-2 associated X protein; Bcl-2: B-cell lymphoma protein 2; DHE: Dihydroethidium

\section{Competing interests}

The authors declare that there is no conflict of interests.

\section{Authors' contributions}

SZM and HAK conceived and designed the study. SZM, MP, ER and HK performed the experiments. SZM, MP and HK analysed the data. SZM and HAK contributed reagents/materials/analysis tools. SZM wrote the manuscript. All authors read and approved the final manuscript.

\section{Acknowledgements}

This research was supported by the High Impact Research Chancellery Grant UM.C/625/1/HIR/175 from the University of Malaya, University of Malaya Research Grant (RP001-2012C) and Postgraduate Research Fund (PG1182013A).

\section{Author details}

'Biomolecular Research Group, Biochemistry Program, Institute of Biological Sciences, Faculty of Science, University of Malaya, Kuala Lumpur, Malaysia. 2Department of Pharmacology, Faculty of Medicine, University of Malaya, Kuala Lumpur, Malaysia. ${ }^{3}$ Department of Pharmacy, Faculty of Medicine, University of Malaya, Kuala Lumpur, Malaysia.

Received: 19 June 2014 Accepted: 5 August 2014

Published: 15 August 2014

\section{References}

1. Ramezanpour M, da Silva KB, Sanderson BJ: Venom present in sea anemone (heteractis magnifica) induces apoptosis in non-small-cell lung cancer A549 cells through activation of mitochondria-mediated pathway. Biotechnol Lett 2012, 36(3):1-7.

2. Siegel R, DeSantis C, Virgo K, Stein K, Mariotto A, Smith T, Cooper D, Gansler T, Lerro C, Fedewa S, Lin C, Leach C, Cannady RS, Cho H, Scoopa S, Hachey M, Kirch $R$, Jemal A, Ward E: Cancer treatment and survivorship statistics, 2012. CA-Cancer J Clin 2012, 62(4):220-241.

3. Mitsudomi T, Morita S, Yatabe Y, Negoro S, Okamoto I, Tsurutani J, Seto T, Satouchi M, Tada H, Hirashima T, Asami K, Katakami N, Takada M, Yoshioka H, Shibata K, Kudoh S, Shimizu E, Saito H, Toyooka S, Nakagawa K, Fukuoka M: Gefitinib versus cisplatin plus docetaxel in patients with non-smallcell lung cancer harbouring mutations of the epidermal growth factor receptor (WJTOG3405): an open label, randomised phase 3 trial. Lancet Oncol 2010, 11(2):121-128.

4. Kim SS, Cho HJ, Kang JY, Kang HK, Yoo TK: Inhibition of androgen receptor expression with small interfering RNA enhances cancer cell apoptosis by suppressing survival factors in androgen insensitive, late stage LNCaP cells. Sci World J 2013, 2013. doi:10.1155/2013/519397.

5. Ocker M, Höpfner M: Apoptosis-modulating drugs for improved cancer therapy. Eur Surg Res 2012, 48(3):111-120.
6. Schumacker PT: Reactive oxygen species in cancer cells: live by the sword, die by the sword. Cancer Cell 2006, 10(3):175-176.

7. Moghadamtousi SZ, Goh BH, Chan CK, Shabab T, Kadir HA: Biological activities and phytochemicals of swietenia macrophylla king. Molecules 2013, 18(9):10465-10483

8. Simon $\mathrm{H}-\mathrm{U}$, Haj-Yehia A, Levi-Schaffer F: Role of reactive oxygen species (ROS) in apoptosis induction. Apoptosis 2000, 5(5):415-418.

9. Martinou J-C, Youle RJ: Mitochondria in apoptosis: $\mathrm{BCl}-2$ family members and mitochondrial dynamics. Dev Cell 2011, 21(1):92-101.

10. Yang F, Jove $V$, Chang $S$, Hedvat M, Liu L, Buettner R, Tian $Y$, Scuto A, Wen W, Yip MLR, Meter TV, Yen Y, Jove R: Bortezomib induces apoptosis and growth suppression in human medulloblastoma cells, associated with inhibition of AKT and NF-kB signaling, and synergizes with an ERK inhibitor. Cancer Biol Ther 2012, 13(6):349-357.

11. Van Waes $\mathrm{C}$ : Nuclear factor-KB in development, prevention, and therapy of cancer. Clin Cancer Res 2007, 13(4):1076-1082.

12. Adewole SO, Caxton-Martins EA: Morphological changes and hypoglycemic effects of annona muricata Linn.(annonaceae) leaf aqueous extract on pancreatic $\beta$-cells of streptozotocin-treated diabetic rats. Afr J Biomed Res 2006, 9(3):173-187.

13. Adewole SO, Ojewole JA: Protective effects of annona muricata Linn. (annonaceae) leaf aqueous extract on serum lipid profiles and oxidative stress in hepatocytes of streptozotocin-treated diabetic rats. Afr J Tra Compl Alter Med 2009, 6(1):30.

14. George VC, Kumar DN, Rajkumar V, Suresh P, Ashok R: Quantitative assessment of the relative antineoplastic potential of the $n$-butanolic leaf extract of annona muricata Linn. In normal and immortalized human cell lines. Asian Pac J Cancer P 2012, 13(2):699-704.

15. Mishra S, Ahmad S, Kumar N, Sharma BK: Annona muricata (the cancer killer): a review. Glob J Pharma Res 2013, 2(1):1613-1618.

16. Ezirim $A \cup$, Okachi $V I$, James AB, Adebeshi OA, Ogunnowo S, Odeghe OB: Induction of apoptosis in myelogenous leukemic K562 cells by ethanolic leaf extract of annona muricata. Indian J Drugs Dis 2013, 2(3):142-151.

17. Zeng L, Wu F-E, Oberlies NH, McLaughlin JL, Sastrodihadjo S: Five new monotetrahydrofuran ring acetogenins from the leaves of annona muricata. J Nat Prod 1996, 59(11):1035-1042

18. Mosmann T: Rapid colorimetric assay for cellular growth and survival: application to proliferation and cytotoxicity assays. J Immunol Methods 1983, 65(1):55-63.

19. Liew SY, Looi CY, Paydar M, Cheah FK, Leong KH, Wong WF, Mustafa MR, Litaudon M, Awang K: Subditine, a new monoterpenoid indole alkaloid from bark of nauclea subdita (korth.) steud. Induces apoptosis in human prostate cancer cells. PLoS One 2014, 9(2):e87286.

20. Looi CY, Moharram B, Paydar M, Wong YL, Leong KH, Mohamad K, Arya A, Wong WF, Mustafa MR: Induction of apoptosis in melanoma A375 cells by a chloroform fraction of centratherum anthelminticum (L.) seeds involves NF-kappaB, p53 and Bcl-2-controlled mitochondrial signaling pathways. BMC Complem Altern M 2013, 13(1):166.

21. Chan FK-M, Moriwaki K, De Rosa MJ: Detection of Necrosis by Release of Lactate Dehydrogenase Activity. In Immune Homeostasis. Edited by Snow AL, Lenardo MJ. New York: Humana Press; 2013:65-70.

22. Häcker G: The morphology of apoptosis. Cell Tissue Res 2000, 301(1):5-17.

23. Ovadje P, Chatterjee S, Griffin C, Tran C, Hamm C, Pandey S: Selective induction of apoptosis through activation of caspase-8 in human leukemia cells (Jurkat) by dandelion root extract. J Ethnopharmacol 2011, 133(1):86-91.

24. Rajagopalan V, Hannun YA: Sphingolipid Metabolism and Signaling as a Target for Cancer Treatment. In Cell Death Signaling in Cancer Biology and Treatment. Edited by Johnson DE. New York: Springer press; 2013:205-229.

25. Ding X, Zhu F-S, Li M, Gao S-G: Induction of apoptosis in human hepatoma SMMC-7721 cells by solamargine from solanum nigrum $\mathrm{L}$. J Ethnopharmacol 2012, 139(2):599-604.

26. Elmore S: Apoptosis: a review of programmed cell death. Toxicol Pathol 2007, 35(4):495-516.

27. Arur S, Uche UE, Rezaul K, Fong M, Scranton V, Cowan AE, Mohler W, Han DK: Annexin I is an endogenous ligand that mediates apoptotic cell engulfment. Dev Cell 2003, 4(4):587-598.

28. Park M-T, Lee S-J: Cell cycle and cancer. J Biochem Mol Biol 2003, 36(1):60-65.

29. Pucci B, Kasten M, Giordano A: Cell cycle and apoptosis. Neoplasia 2000, 2(4):291-299.

30. Zorofchian Moghadamtousi S, Karimian H, Khanabdali R, Razavi M, Firoozinia M, Zandi K, Kadir HA: Anticancer and antitumor potential of fucoidan and 
fucoxanthin. Two main metabolites isolated from brown algae. Sci World J 2014, 2014. doi:10.1155/2014/768323.

31. Li T, Kon N, Jiang L, Tan M, Ludwig T, Zhao Y, Baer R, Gu W: Tumor suppression in the absence of p53-mediated cell-cycle arrest, apoptosis, and senescence. Cell 2012, 149(6):1269-1283.

32. Adams DJ, Boskovic ZV, Theriault JR, Wang AJ, Stern AM, Wagner BK, Shamji AF, Schreiber SL: High-throughput screening identifies small-molecule enhancers of reactive oxygen species that are nontoxic or cause genotype-selective cell death. ACS Chem Biol 2013, 8(5):923-929.

33. Circu ML, Aw TY: Reactive oxygen species, cellular redox systems, and apoptosis. Free Radic Biol Med 2010, 48(6):749-762.

34. Kushnareva Y, Andreyev AY, Kuwana T, Newmeyer DD: Bax activation initiates the assembly of a multimeric catalyst that facilitates Bax pore formation in mitochondrial outer membranes. PLOS Biol 2012, 10(9):e1001394.

35. Saelens X, Festjens N, Walle LV, Grup MV, Loo GV, Vandenabeele P: Toxic proteins released from mitochondria in cell death. Oncogene 2012, 23(16):2861-2874. 2012.

36. Hill MM, Adrain C, Duriez PJ, Creagh EM, Martin SJ: Analysis of the composition, assembly kinetics and activity of native Apaf-1 apoptosomes. EMBO J 2004, 23(10):2134-2145.

37. Mondragón L, Orzáez M, Gortat A, Sancho M, Messeguer A, Vicent MJ, Perez-Paya E: Molecules That Bind a Central Protein Component of the Apoptosome, Apaf-1, and Modulate Its Activity. In Apoptosome. Edited by Cecconi F, D'Amelio M. Netherlands: Springer press; 2010:75-94.

38. Callus B, Vaux D: Caspase inhibitors: viral, cellular and chemical. Cell Death Differ 2006, 14(1):73-78.

39. Delgado ME, Olsson M, Lincoln FA, Zhivotovsky B, Rehm M: Determining the contributions of caspase-2, caspase-8 and effector caspases to intracellular VDVADase activities during apoptosis initiation and execution. BBA-Mol Cell Res 2013, 1833(10):2279-2292.

40. Cory S, Adams JM: The Bcl2 family: regulators of the cellular life-or-death switch. Nat Rev Cancer 2002, 2(9):647-656.

41. Zamzami N, Kroemer G: The mitochondrion in apoptosis: how Pandora's box opens. Nat Rev Mol Cell Bio 2001, 2(1):67-71.

42. Bhardwaj A, Sethi G, Vadhan-Raj S, Bueso-Ramos C, Takada Y, Gaur Y, Nair AS, Shishodia S, Aggarwal BB: Resveratrol inhibits proliferation, induces apoptosis, and overcomes chemoresistance through down-regulation of STAT3 and nuclear factor-kB-regulated antiapoptotic and cell survival gene products in human multiple myeloma cells. Blood 2007, 109(6):2293-2302.

43. Baldwin AS: Control of oncogenesis and cancer therapy resistance by the transcription factor NF-KB. J Clin Invest 2001, 107(3):241-246.

doi:10.1186/1472-6882-14-299

Cite this article as: Moghadamtousi et al:: Annona muricata leaves induced apoptosis in A549 cells through mitochondrial-mediated pathway and involvement of NF-KB. BMC Complementary and Alternative Medicine 2014 14:299.

\section{Submit your next manuscript to BioMed Central and take full advantage of:}

- Convenient online submission

- Thorough peer review

- No space constraints or color figure charges

- Immediate publication on acceptance

- Inclusion in PubMed, CAS, Scopus and Google Scholar

- Research which is freely available for redistribution 